\title{
Satellite mapping and stabilization of the aeolian deposits of QAFCO site 5/6
}

\author{
Rajendran S ${ }^{1}$, Sadooni FN ${ }^{1}$, Zouari N ${ }^{2}$, Dimassi SN ${ }^{2}$, Al-Jabri, A ${ }^{3}$, Al-Kuwari Al-Saad H ${ }^{1}$ \\ ${ }^{1}$ Environmental Science Center, Qatar University, P.O. Box 2713, Doha, Qatar; ${ }^{2}$ Environmental Science Program, College of Science, P.O. Box: 2713, Doha, Qatar; \\ ${ }^{3}$ Environment Division, Qatar Fertilizer Company, PO Box 50001, Mesaieed, Qatar.
}

\section{ABSTRACT}

Aeolian processes produce vast areas of sand and dunes in the arid region and need to monitor since they encroaching land and degrading infrastructures. In this study, we used the satellite data of ASTER and mineral indices namely quartz index (QI) and carbonate index (Cl), and identified and discriminated the sand deposits, dunes, and associated rock formations that occurred in and around the OAFCO site 5/6, Qatar. The mapping of the area using high spatial resolution WorldView-2 satellite data confirmed the presence of sand deposits, dunes, and sand encroachments in the site. Our field studies validated the satellite data results/ The grain size analyses of samples showed that the deposits have predominantly sand grains (81.3 to $99.81 \%)$. The XRD analyses of samples identified the presence of quartz, calcite, dolomite, albite, and halite minerals. These are confirmed by geochemical analyses which showed the high concentration of $\mathrm{SiO}_{2}, \mathrm{Al}_{2} \mathrm{O}_{3}, \mathrm{CaO}, \mathrm{MgO}, \mathrm{Na}_{2} \mathrm{O}, \mathrm{CO}_{3}, \mathrm{SO}_{4}, \mathrm{Cl}$, and $\mathrm{B}$. In addition, the study of sand stabilization by bacteria method to stop the erosion at selected places of the site showed the applicability of the technique. All results allowed us to assess the implications of the deposits and encroachments at the industry site.

\section{Introduction}

Sand deposits and encroachment by sand movement in the northwest and southeast part of the State of Qatar are high and a detailed study to mitigate and/or protect this phenomenon at the QAFCO site $5 / 6$ is needed. Mapping of and deposits, measuring migration rates of dunes, and the direction of the movement of dunes are studied and monitored (Aydda et al., 2020). Importantly, the remote sensing techniques help to map the sand deposits and monitor the sand movements and assess the sand encroachments (Engel et al., 2018). The satellite data acquired in the visible, near-infrared, and shortwave infrared spectral regions $(0.4-2.5 \mu \mathrm{m})$ are useless for detecting quartz minerals because the quartz does not show spectral features in the pectral regions and exhibits a strong doublet emissivity feature in the longwave infrared LWIR spectral region. The 8$14 \mu \mathrm{m} \mathrm{(LWIR} \mathrm{)} \mathrm{is} \mathrm{suitable} \mathrm{for} \mathrm{the} \mathrm{identification} \mathrm{and}$ quantification of the minerals of aeolian deposits (Eisele et al. 20115) and mapping of dunes. This study 1) describes the spectral absorptions of quartz and carbonate minerals, 2 discriminates and maps the sand deposits and dunes that occurred in and around the QAFCO site 5/6 using the TIR bands of ASTER and quartz and carbonate indices (Ninomiya et al, 2005. Rajendran and Nasir, 2019), 3) characterizes the physicochemical characters of the sand and 4) studies the sand stabilization by bacteria method to understand the occurrence and spatial distribution of the sand deposits and protect the encroachment in the industry site. The study assesses the areas that are vulnerable to sand encroachment and land degradation using WorldView-2 data (Rajendran et al., 2021) to understand the implications of the sand deposits and sand encroachments at the QAFCO site $5 / 6$.

\section{ASTER Mineral Indices}

In this study, the Quartz and Carbonate minerals indices of ASTER bands are used. The indices are described as

Quartz Index $(\mathrm{Q})=($ Band11 $) \times($ Band11 $) /($ Band10 $) \times$ (Band12)

Where, QI is expected to be high for quartz and other siliceous rocks, but low for potassium feldspar and gypsum

\section{and, Carbonate Index $(\mathrm{Cl})=$ Band13 $/$ Band 14}

Where, $\mathrm{Cl}$ is expected to be high for the carbonate minerals such as calcite and dolomite, but the index is not expected to identify other carbonate rocks (Ninomiya et al. 2005; Ninomiya, 2002).

\section{RESULTS}

Mapping of sand deposits and sand encroachments: The study of spectral emissive properties of the quartz and carbonate minerals showed that the quartz and unaltered silicate minerals have prominent spectral features between 8.12 to $9.27 \mu \mathrm{m}$ due to the fundamental asymmetric $\mathrm{Si}-\mathrm{O}-\mathrm{Si}$ stretching vibrations and the carbonate minerals have emissivity minima near 11.4 $\mu \mathrm{m}$ for calcite and $11.2 \mu \mathrm{m}$ for dolomite due to the $\mathrm{C}-\mathrm{O}$ bending. Based on this, a false-color composite (FCC) was developed using the ASTER band 6, QI, and $\mathrm{Cl}$ which discriminated well the sand deposits and dunes that occurred in and around the QAFCO site 5/6 in bright yellow and associated carbonate formations in purple-pink (Fig. 1). The large-scale mapping of the area using high spatial resolution data of WorldView-2 satellite data confirmed further the presence of sand deposits, dunes, and sand encroachments along the fences constructed in the northwest and southwest sides of the site (Fig. 2). The interpretation of the image showed the areas that are vulnerable to sand encroachment and land degradation.

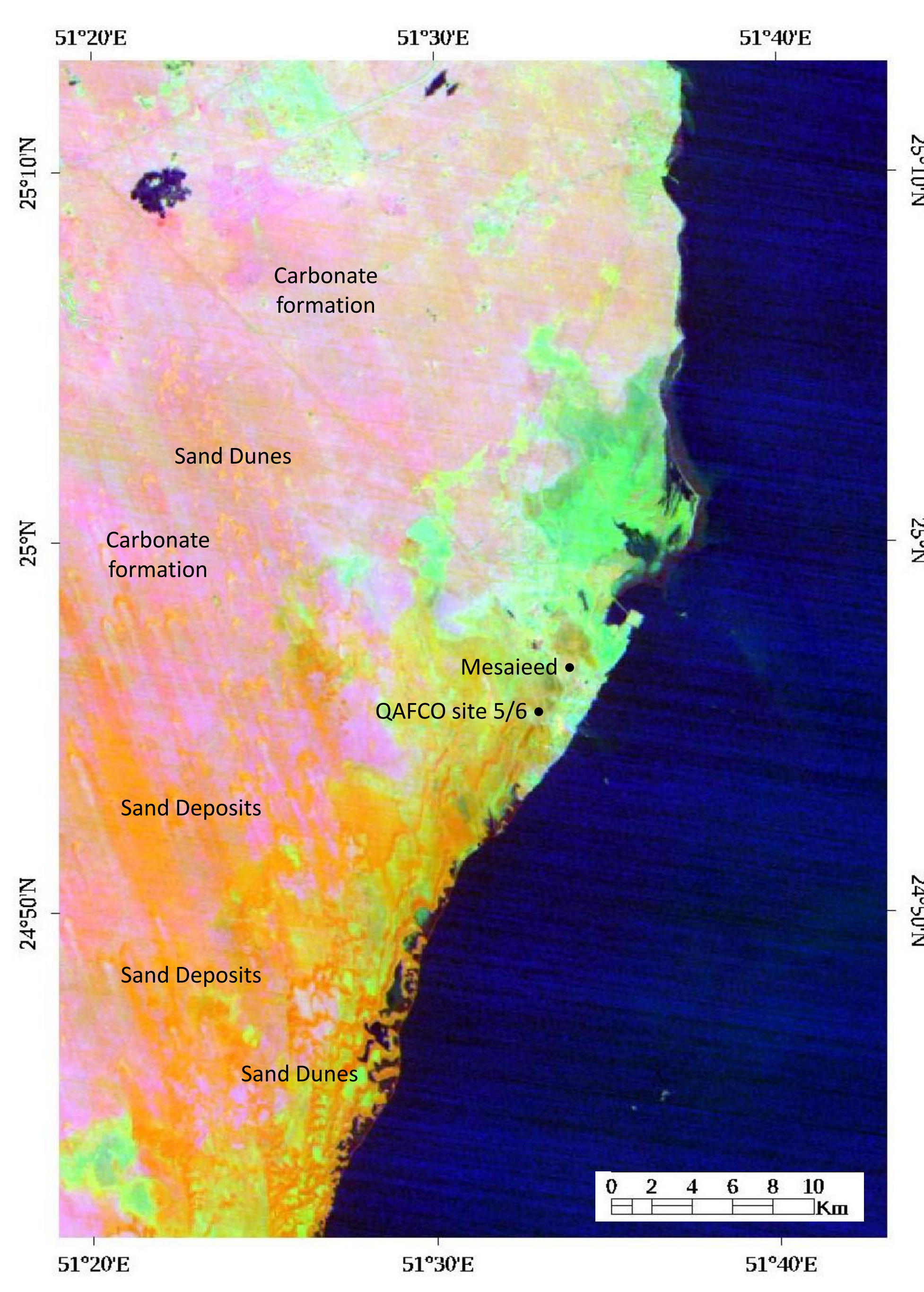

Fig. 1. False-color composite (R: Band 6; G: Quartz index; B: Cl index) showing the regional occurrence and distribution of sand, dunes, and carbonate formations in the east coast transect of the State of $Q$ atar.

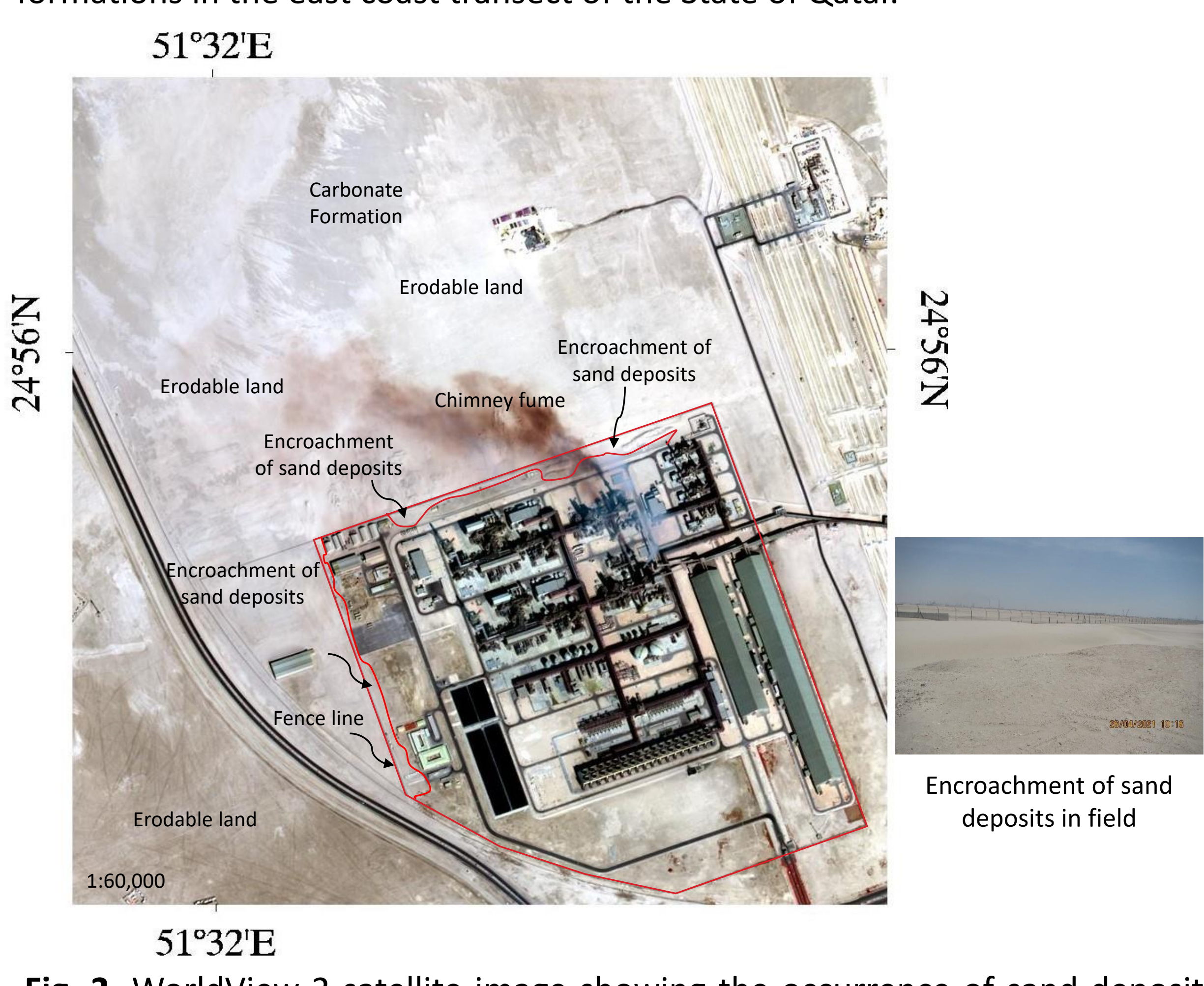

ig. 2 .

near the fence and around the QAFCO site 5/6.

Field and laboratory studies: In the field, the presence of sand deposits and sand encroachments that occurred along the fences built at the northwest and southwest sides are verified. The deposits are not much on the northeast and southeast sides. The grain size analyses of the field samples showed the presence of a high amount of sand grains ( 81.3 to $99.81 \%$ ), a low amount of silt 0.19-17.43), and a very little amount of clay (1.27 to 1.36$)$ in the sand deposits. The XRD analyses of the samples for identification of minerals showed the presence of quartz, calcite, magnesian calcite, dolomite, albite (quartz silicate), and halite minerals in the samples (Fig. 3).
The elemental analyses of samples showed that the samples are rich in $\mathrm{SiO}_{2}, \mathrm{Al}_{2} \mathrm{O}_{3}, \mathrm{CaO}, \mathrm{MgO}, \mathrm{Na}_{2} \mathrm{O}, \mathrm{CO}_{3}, \mathrm{SO}_{4}, \mathrm{Cl}$, and $\mathrm{B}$ which reflects the presence of quartz and carbonate minerals such as calcite and dolomite in the samples.

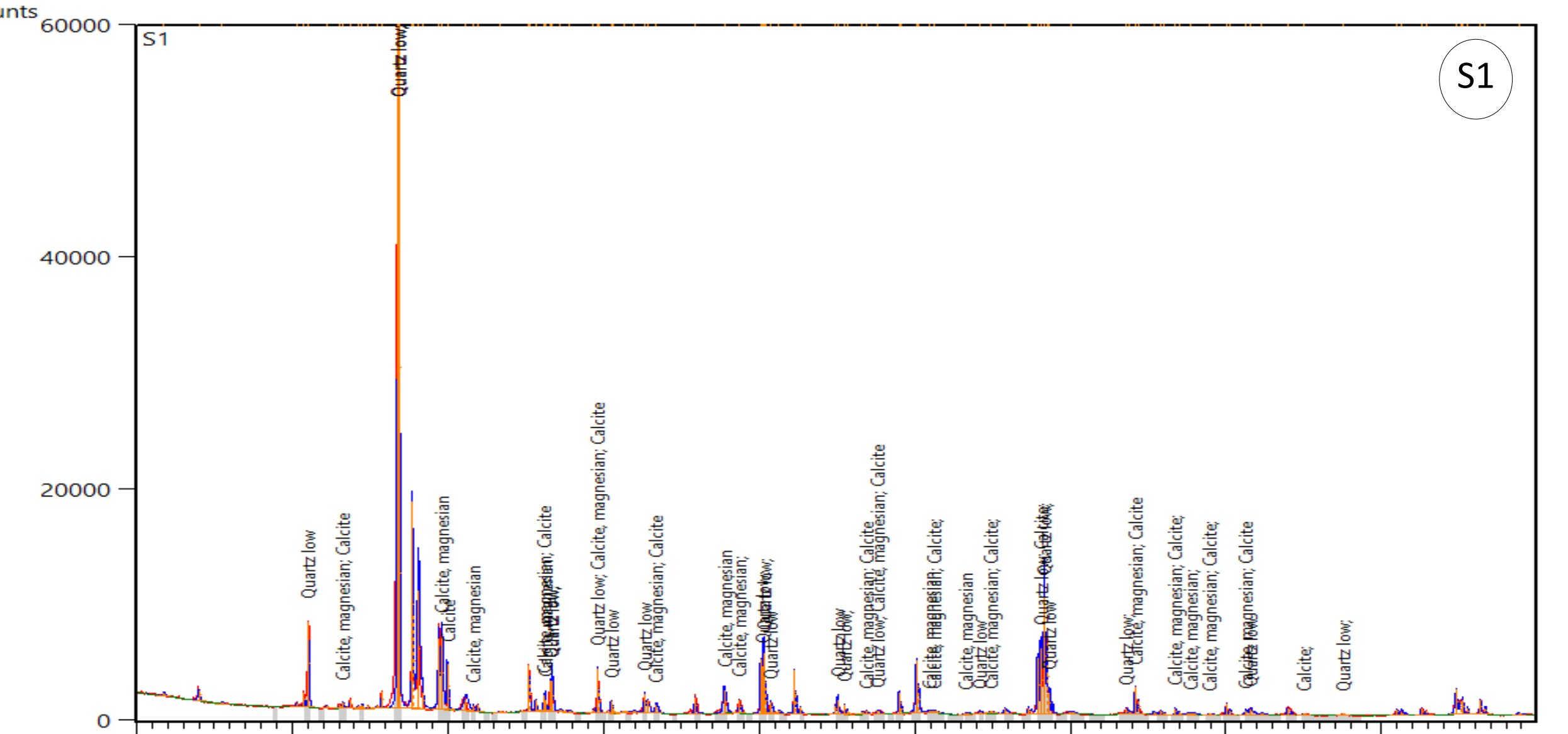

Fig. 3. An example of the result of XRD analysis.

Sand stabilization by bacteria method: The study of sand stabilization to stop the sand erosion provided the 12 ureolytic bacteria strains that have high urease activities (Table 1) and the sands are stimulated well by the bacteria for cementation and stabilization. The study of minerals in the isolates by FTIR method showed the presence of calcium carbonate phases (Calcite), in addition to calcium phosphates (Apatite).

Table 1. Arbitrary urease activity (AUA) and its specific production of isolates
\begin{tabular}{|l|r|r|r|}
\hline Isolate & $\begin{array}{c}\text { CFU (10 } \\
\text { cfu/mL) }\end{array}$ & $\begin{array}{c}\text { Arbitrary } \\
\text { urease activity } \\
\text { (AUA/ mL) }\end{array}$ & $\begin{array}{c}\text { Specifc production } \\
\text { (AUA/107 cfu) }\end{array}$ \\
\hline S1.1 & $6 \pm 0.3$ & $1.59 \pm 0.1$ & $2.9 \pm 0.1$ \\
\hline S1.2 & $10 \pm 1$ & $3.92 \pm 0.2$ & $4.1 \pm 0.2$ \\
\hline S1.3 & $6 \pm 0.3$ & $7.36 \pm 0.4$ & $12.7 \pm 0.5$ \\
\hline S1.4 & $3 \pm 0.1$ & $3.55 \pm 0.2$ & $12.9 \pm 0.3$ \\
\hline S1.5 & $5 \pm 0.2$ & $9.65 \pm 0.5$ & $20.5 \pm 0.8$ \\
\hline S1.7 & $39 \pm 2$ & $9.68 \pm 0.5$ & $2.5 \pm 0.2$ \\
\hline S1.8 & $71 \pm 4$ & $12.55 \pm 0.6$ & $1.8 \pm 0.3$ \\
\hline S1.9 & $10 \pm 1$ & $1.58 \pm 0.1$ & $1.5 \pm 0.1$ \\
\hline S3.2 & $20 \pm 1$ & $11.86 \pm 0.6$ & $5.9 \pm 0.2$ \\
\hline S3.3 & $9 \pm 0.4$ & $20.57 \pm 1$ & $23.6 \pm 2.1$ \\
\hline S3.4 & $5 \pm 0.2$ & $19.24 \pm 1$ & $39.3 \pm 1.6$ \\
\hline S5.3 & $7 \pm 0.4$ & $16.54 \pm 0.8$ & $22.3 \pm 1.9$ \\
\hline
\end{tabular}

\section{CONCLUSION}

In this study, we utilized the satellite data to map the aeolian deposits and demonstrated the capability of satellite sensors to map the deposits and sand encroachments that found in the QAFCO site 5/6 for remedial measures.

\section{ACKNOWLEDGEMENT}

This study is supported by Qatar University Grant no. QUEX-ESCQAFCO-20/21-1. We are thankful to the NASA Land Processes Distributed Active Archive Center User Services, USGS Earth Resources Observation and Science (EROS) Center (https://LPDAAC. usgs.gov) for sharing the ASTER data and the Digital Globe, USA is acknowledged for providing the WorldView-2 satellite image (Image ID: 104001004D7C7D00) that was acquired on February 16, 2021.

\section{REFERENCES}

Aydda, A., Althuwaynee, O.F., Pokhare, B. 2020. An easy method for barchan dunes automatic extraction from multispectral satellite data. IOP Conf. Series: Earth and Environmental Science 419. 012015.

Eisele, A., Chabrillat, S., Hecker, C., Hewson, R., Lau, I.C., Rogass, C., Segl, K., Cudahy, T.J., Udelhoven, T., Hostert, P., et al. 2015. Advantages using the thermal infrared (TIR) to detect and quantify semi-arid soil properties. Remote Sens. Environ. 163,296-311.

Engel, M., Boesl, F., Brückner, H., 2018. Migration of Barchan Dunes in Qatar-Controls of the Shamal, Teleconnections, Sea-Level Changes and Human Impact. Geosciences 8, 240.

Ninomiya, Y., Fu, B., Cudahy, T.J. 2005. Detecting lithology with advanced spaceborne thermal emission and reflection radiometer (ASTER) multispectral thermal infrared "radiance-at-sensor" data. Remote Sens. Environ. 99, 127-139

(r. 2002. Mapping quartz, carbonate minerals and maficultramafic rocks using remotely sensed multispectral thermal infrared ASTER data. P SPIE 4710:191-202

Rajendran. S., Nasir. S. 2019. ASTER capability in mapping of minera the the Sultanate of Oman. Ore Geology Reviews. 108, 33-53.

Rajendran, S., Jassim A. Al-Khayat., Veerasingam, S., Nasir. S., Vethamony, P., Fadhil N. Sadooni., Hamad Al Saad., 2021. WorldView-3 mapping of Tar deposits of the Jazirat Ras Rakan Island, Northern Coast of Qatar Environmental perspective. Marine Pollution Bulletin 163, 111988. 